\title{
Development of Cool Roof Calculator for India
}

Vishal Garg, Shikher Somal, Rathish Arumugam, Aviruch Bhatia

\begin{tabular}{|l|c|l|}
\hline \multicolumn{1}{|c|}{ Author } & \multicolumn{1}{|c|}{ email } & \multicolumn{1}{c|}{ Affiliation } \\
\hline Vishal Garg & vishal@iiit.ac.in & $\begin{array}{l}\text { International Institute of Information } \\
\text { Technology, Hyderabad (India) }\end{array}$ \\
\hline Shikher Somal & shikher111@gmail.com & $\begin{array}{l}\text { International Institute of Information } \\
\text { Technology, Hyderabad (India) }\end{array}$ \\
\hline Rathish Arumugam & rathish.iiit@gmail.com & $\begin{array}{l}\text { International Institute of Information } \\
\text { Technology, Hyderabad (India) }\end{array}$ \\
\hline Aviruch Bhatia & aviruch@ hotmail.com & $\begin{array}{l}\text { International Institute of Information } \\
\text { Technology, Hyderabad (India) }\end{array}$ \\
\hline
\end{tabular}

\begin{abstract}
In tropical countries such as India, increasing the roof albedo helps to reduce the heat ingress through the roof. This further reduces air-conditioning energy consumption in conditioned buildings and increases comfort in unconditioned buildings. In order to help users determine the benefits of high albedo roofs under varying conditions, a simple calculator has been developed. Parameters such as location, building type, roof area, and surface properties of the roof are taken as inputs. Annual EnergyPlus simulations are performed for the given parameters and the results are displayed in both graphical and tabular formats. It also calculates the simple payback by comparing a given base case roof albedo with the proposed roof albedo. The calculator can perform comfort simulations for unconditioned buildings and simulates measures including a radiant barrier system and under deck roof insulation. The calculator also runs a parametric simulation between insulation thickness and roof albedo to find an optimum roof insulation thickness based on Incremental Internal Rate of Return. This paper presents the features of the cool roof calculator and the type of analysis that can be performed using the cached results.
\end{abstract}

\section{Introduction}

A roof that reflects and emits the solar radiation back to the sky rather than transferring it into the building is termed a cool roof [1]. Cool roofs help reduce air-conditioning energy consumption in a conditioned building and improve thermal comfort in an unconditioned building in hot climates. The energy savings achieved in a building from cool roofs is dependent on various parameters such as the location, orientation of the 
building, local shading by trees or other buildings, construction type, insulation type, plenum ventilation, equipment load, occupancy and operational schedules [2]. There have been several studies [3], [4] and [5] to demonstrate the benefits of cool roofs. Most of them have been experimental studies.

Considering the advantage and flexibility in evaluating the effect of cool roof through simulations and models, research exists in the development of various simulation models and tools calculating the effect of cool roof.

There exists two internet based calculators for understanding the benefits of cool roofs: DOE's Cool Roof Calculator [7], the closely-related DOE Steep Slope Calculator [8], and the Roof Savings Calculator (http://rsc.ornl.gov/). All tools are developed for the United States (US) and either use DOE 2.1 platform for simulations or lookup tables based on data from experimental facilities in the US.

DOE Cool Roof Calculator calculates the annual energy savings in cooling and heating for a given roof solar reflectivity (SR) in comparison with a black roof. The tool also calculates the necessary roof insulation R-value to achieve the same savings as achieved by the given solar reflectivity. This tool supports 243 different locations, with 235 of them belonging to the US, Pacific territories and Puerto Rico, and the remaining 8 to Canada. The inputs that need to be provided by the user in this calculator are $\mathrm{R}$ value, solar reflectivity, infrared emissivity (IE), electricity costs, and HVAC equipment efficiency. The output includes cooling and heating energy savings. This calculator also estimates the energy and peak demand savings for a given solar reflectivity in comparison with a black roof. The input fields are the same. However, the output includes the heat load reduction values during the cooling season. The DOE steep slope calculator performs similar functionality for residential roofs with non black surfaces and for steep roofs.

Roof Savings Calculator (RSC) developed by Oak ridge National Laboratory (ORNL) and Lawrence Berkeley National Laboratory (LBNL), has been recently updated, and is now running in its beta release. The tool has two building categories, residential and commercial, and two modes, simple and advanced. The calculator performs whole building energy simulations using the DOE 2.1E engine for fast energy simulation and integrates AtticSim for advanced modelling of modern attic and cool roofing technologies. The calculator runs an hourly simulation for the provided building properties such as conditioned floor area, number of floors, window details, HVAC details, and the existing and proposed roof details for the selected location. The annual energy savings reported are based upon heating and cooling loads and thus this calculator is only relevant to buildings with a heating and/or cooling unit. New et al. (2012) [8] have discussed interface and UI of the calculator. Jones et al. (2012) [9] built a visual analytics tool to assist in the exploration and identification of features in the data for Roof Savings Calculator simulation ensembles.

For simulating the benefits of cool roofs in Indian climates a tool has been developed by Garg V. et al. (2010) [10] that uses EnergyPlus [11] to perform online simulations. Compared to other tools, the Cool Roof Calculator provides more input details about the building and also more detailed set of results including comfort. Another advantage of the Cool Roof Calculator over the other tools is that it has the capability of simulating an unconditioned building for which the comfort achieved through the use of cool roof will be reported. Therefore, some of the major differences of the Cool Roof Calculator compared to other calculators are the features listed below: 
- Performs online simulation

- Works on EnergyPlus simulation engine

- Capable of modelling an unconditioned space

- Generates thermal comfort results

- Creates payback analysis

- Caching of results

- Works for all major Indian cities

\section{Description of Models}

There are four kinds of building types considered in the calculator - Office, Educational Institute, Retail, and Residential. All these models are square in shape with flat roof. There are five zones in each model - one core and four perimeter. Plan of the model is shown in Figure 1. The base model is generated from EnergyPlus example file generator [12] based ASHRAE 90.1-2007 specifications. The envelope details, lighting power density, equipment power density, and occupancy density of the models used in the tool are summarized in Table 1. The base model was modified as per user inputs at run time and commonly used schedule in such buildings in India. Schedule profile used in the models is shown in Figure 2 Uses pattern for office modelFigure 2 to 6 .

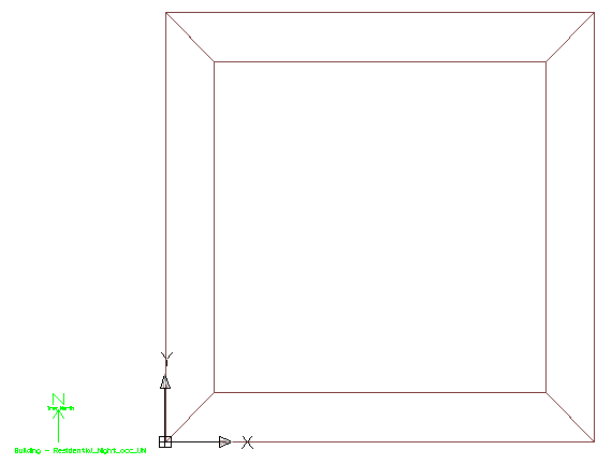

Figure 1 Top view of the model 
Table 1 Input parameters for all models for simple calculator

\begin{tabular}{|c|l|c|c|c|c|}
\hline $\begin{array}{c}\text { S. } \\
\text { No. }\end{array}$ & \multicolumn{1}{|c|}{ Parameter } & Office & $\begin{array}{c}\text { Educational } \\
\text { Institute }\end{array}$ & Retail & Residential \\
\hline 1. & $\begin{array}{l}\text { Exterior Wall } \\
\text { (U-value W/Sqm- } \\
\text { K) }\end{array}$ & 0.70 & 0.70 & 0.70 & 0.70 \\
\hline 2. & $\begin{array}{l}\text { Roof (U-value } \\
\text { W/Sqm-K) }\end{array}$ & 0.94 & 0.94 & 0.94 & 0.94 \\
\hline 3. & $\begin{array}{l}\text { Window } \\
\text { (U-value W/Sqm- } \\
\text { K, SC) }\end{array}$ & $6.8,0.29$ & $6.8,0.29$ & $6.8,0.29$ & $6.8,0.29$ \\
\hline 4. & $\begin{array}{l}\text { Lighting power } \\
\text { density (W/Sqm) }\end{array}$ & 10.76 & 12.91 & 16.14 & 12.91 \\
\hline 5. & $\begin{array}{l}\text { Equipment power } \\
\text { density (W/Sqm) }\end{array}$ & 16.14 & 5.38 & 2.69 & 5.39 \\
\hline 6. & $\begin{array}{l}\text { Occupancy density } \\
\text { (Sqm/ Person) }\end{array}$ & 9.29 & 2.7 & 9.29 & 13.94 \\
\hline
\end{tabular}

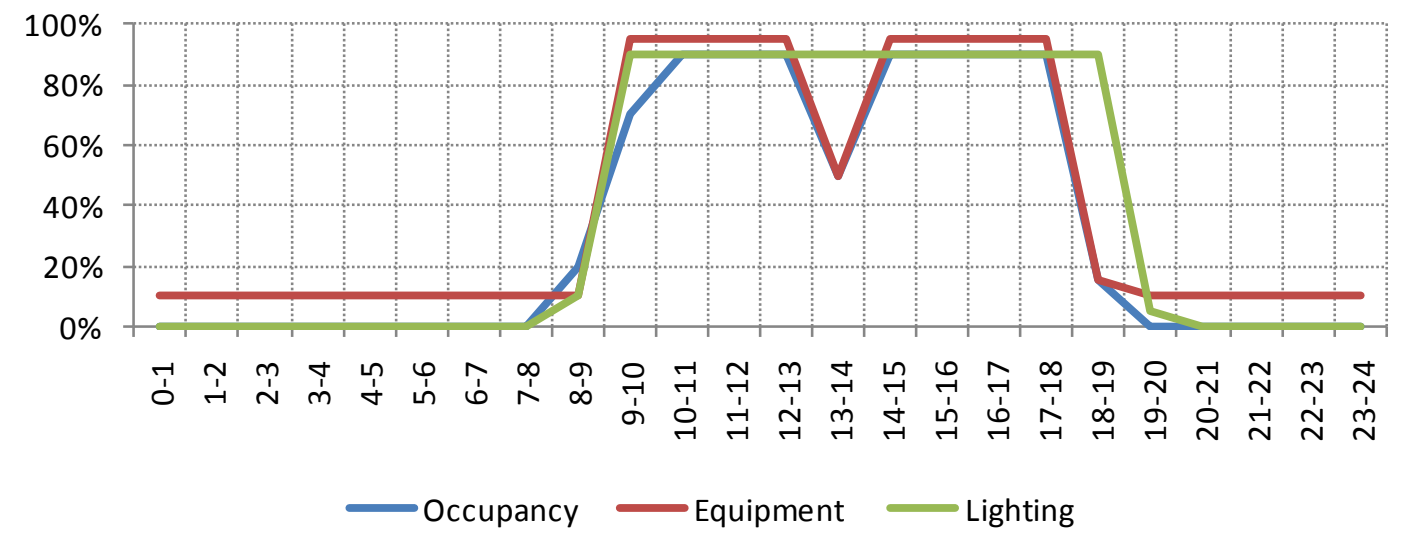

Figure 2 Uses pattern for office model 


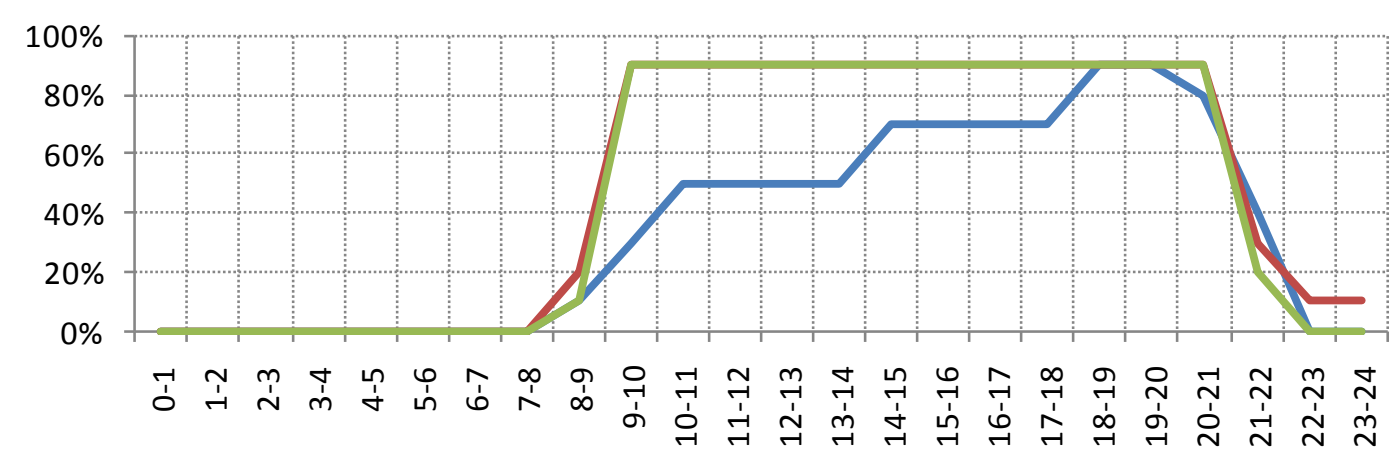

- Occupancy Equipment Lighting

Figure 3 Uses pattern for retail model

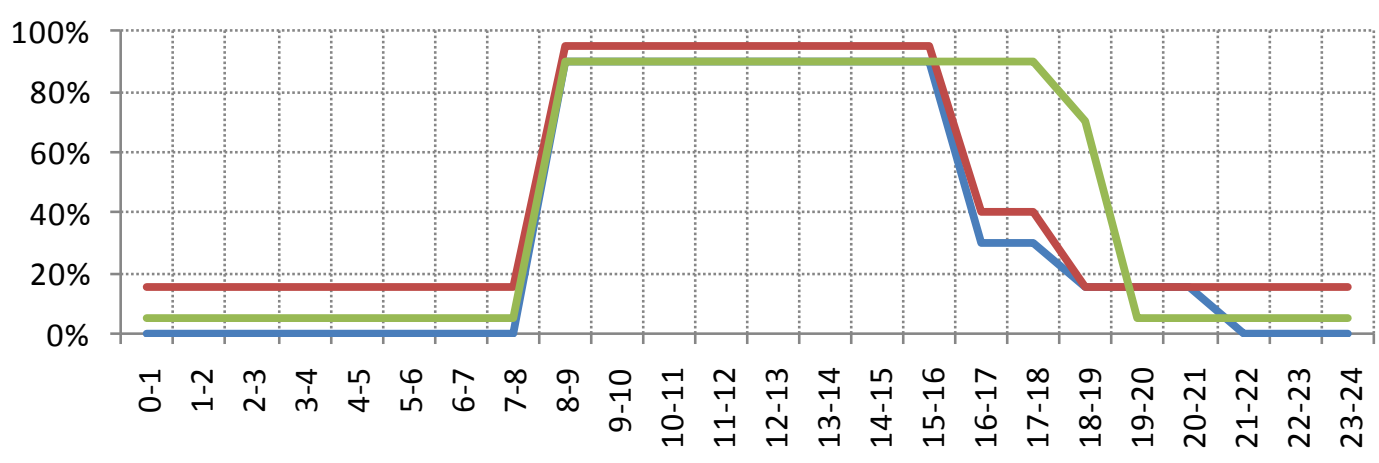

Occupancy $\longrightarrow$ Equipment Lighting

Figure 4 Uses pattern for educational institute model

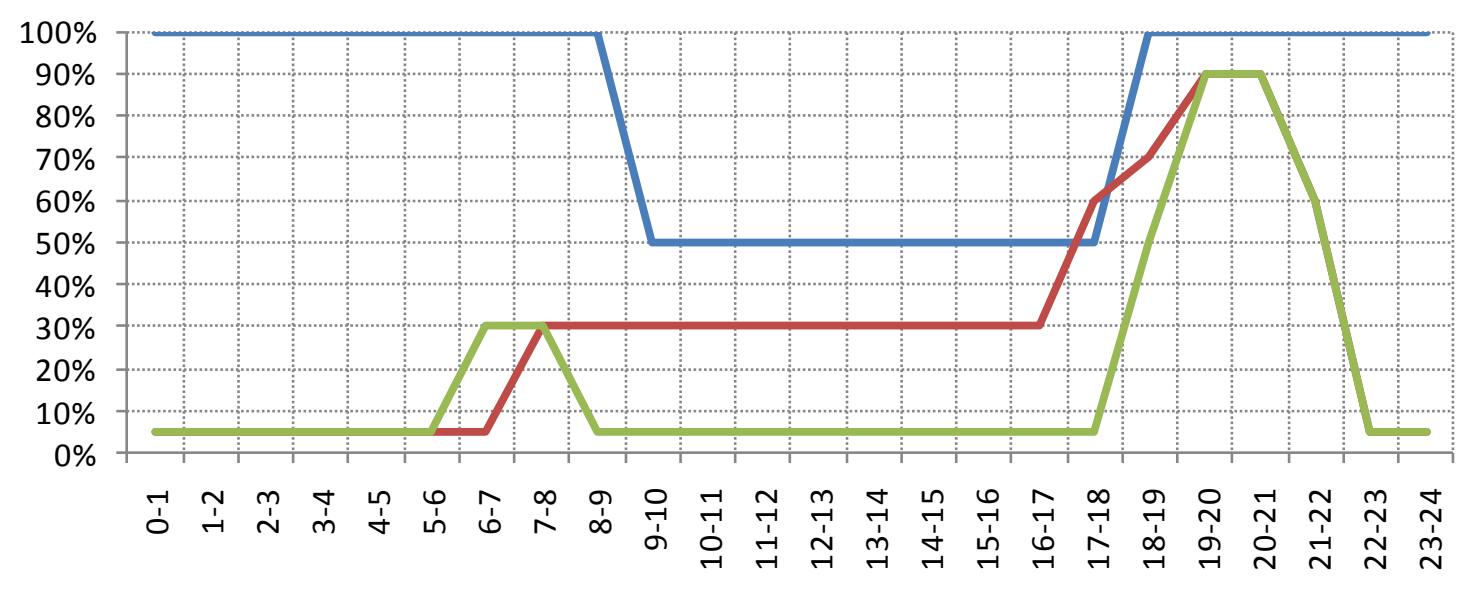

Occupancy $\longrightarrow$ Equipment $\longrightarrow$ Lighting

Figure 5 Uses pattern for Residential model (24 Hrs) 


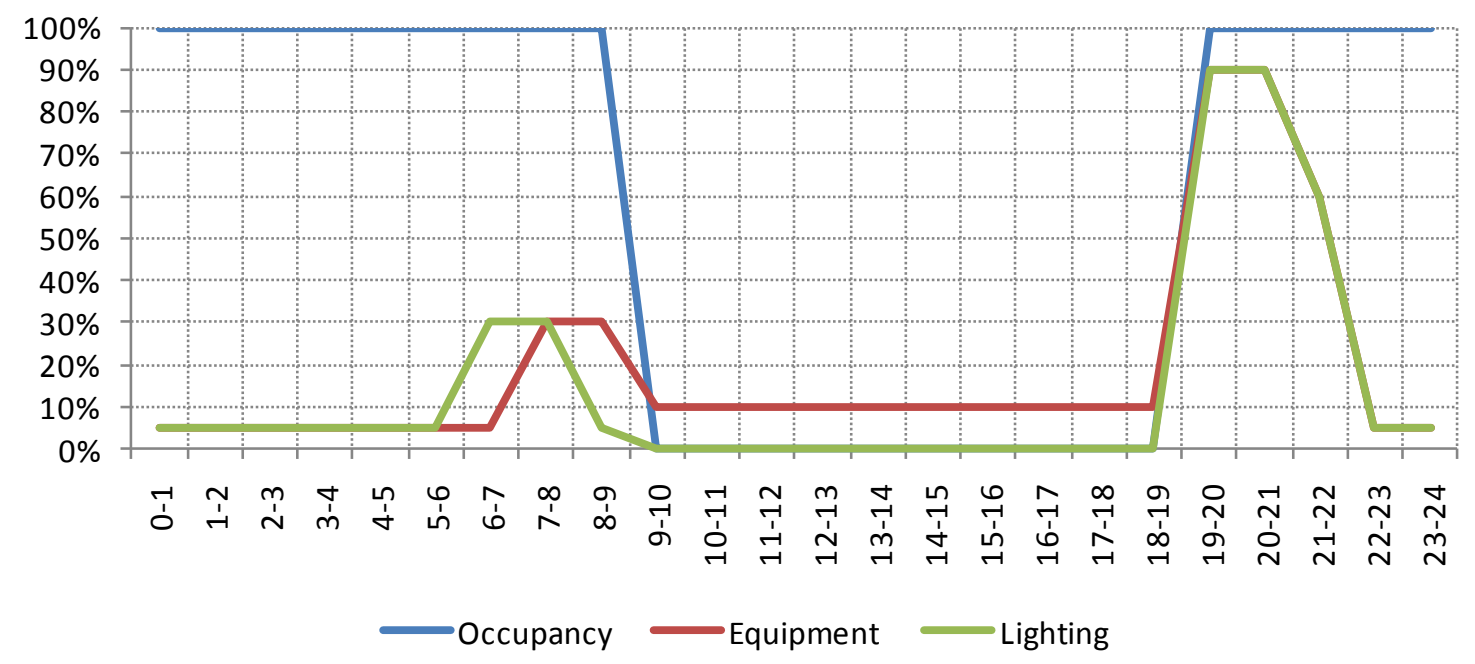

Figure 6 Uses pattern for Residential model (Night time operation)

\section{User Interface and Backend}

The tool is hosted using an Apache/2.2.16 (UNIX) [13]. Web pages are developed in PHP [14] and use other common web technologies like HTML, JS, Ajax, and CSS. The backend is implemented in $\mathrm{C}$ and uses socket programming for efficient communication. The inputs submitted from the User Interface (UI) are posted to a PHP script for simple or detailed case, which generates the corresponding EnergyPlus Input Data File (IDF) for both the normal and the cool roof simulation. The IDF name and the weather file name are then sent to an executable waiting for a socket connection (to open). The executable then calls a bash script which performs the simulations while the front end shows the simulation progress. Once the simulations are done, the UI is redirected to the results page which shows the results.

The calculator_simple.html and calculator_detailed.html pages consist of a form that the user has to fill in order to submit the parameters for the simulation. It consists of various fields such as floor area, window percentage, window, roof, wall, floor types, and so on. On submission of the calculator_simple.html form, either idfgenerator_simple.php or idfgenerator_detailed.php is called depending on which form is submitted. The architecture of the calculator is shown in Figure 7. 


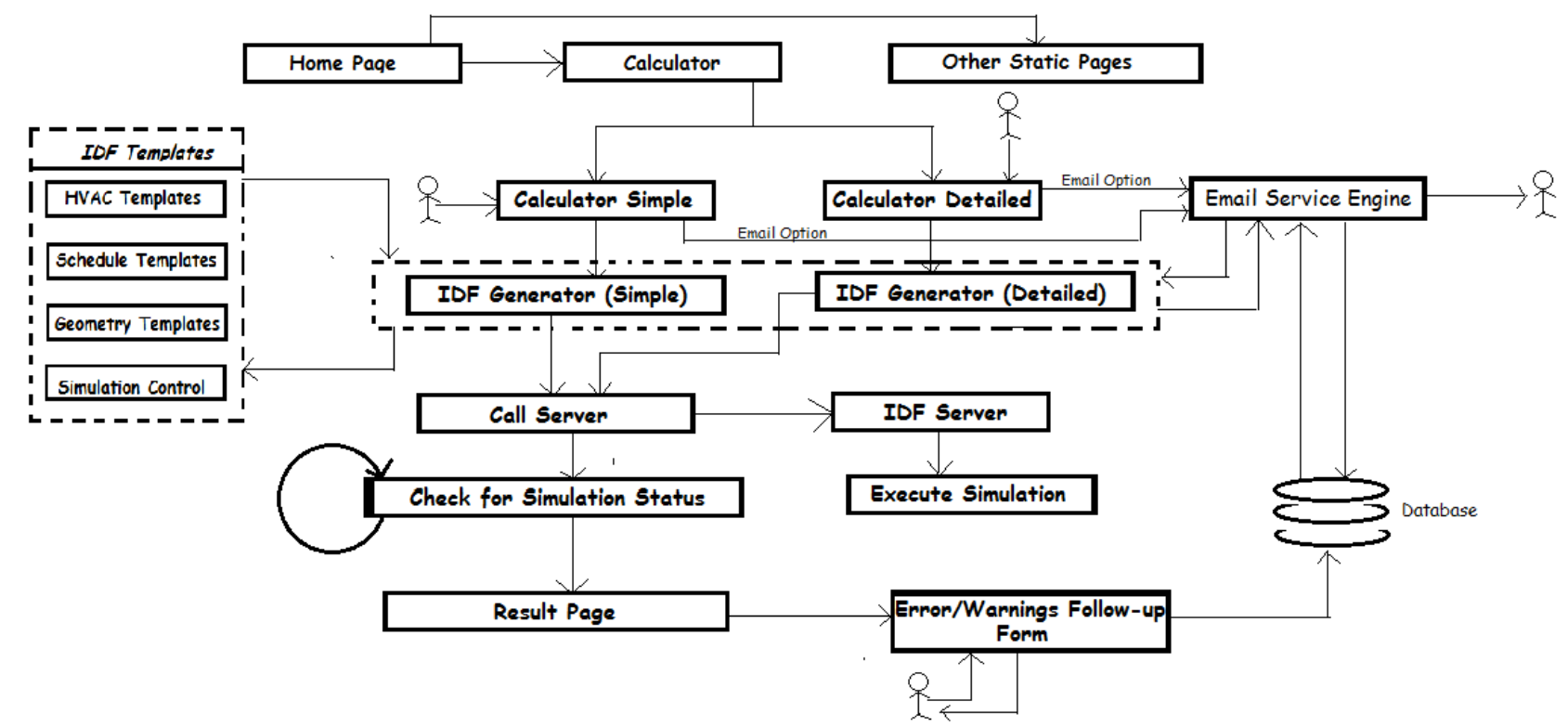

Figure 7 Architecture of the Cool Roof Calculator for India

In case there is any anomaly in the simulation, like the unmet hours are beyond recommended values or Energy Performance Index is not in the specified range, the user gets warning message. For users who do not want to wait for the simulation to complete can get results via email. Once users have filled in the information, they have a choice to run the simulation immediately and wait for the results, or request the results to be emailed by selecting the option - "Email Me the Results". The input and email address are stored in a database.

When compared to the existing cool roof calculators, the calculator developed here is more detailed in terms of the inputs that are to be provided by the user. Broadly, the inputs can be put under the headings of building envelope, internal loads, HVAC, and the location.

\section{Description of HVAC Systems}

This calculator supports four different types of Heating Ventilation and Airconditioning (HVAC) systems are available for selection - Packaged Terminal Heat Pump (PTHP), Packaged Single Zone (PSZ)-HP, Central Air conditioner with water cooled chiller, and Central Air conditioner with air cooled chiller as summarized in Table 2. Each building type can be selected with any one of the available HVAC options. Unconditioned spaces can be simulated by selecting option - No system. 


\begin{tabular}{|l|l|l|l|l|l|l|}
\hline $\begin{array}{l}\text { S. } \\
\text { No. }\end{array}$ & Parameter & PTHP & PSZ-HP & $\begin{array}{l}\text { Central Air } \\
\text { conditioner } \\
\text { Water } \\
\text { cooled } \\
\text { system }\end{array}$ & $\begin{array}{l}\text { Central Air } \\
\text { conditioner } \\
\text { parameters } \\
\text { with air } \\
\text { cooled } \\
\text { chiller } \\
\text { system }\end{array}$ & $\begin{array}{l}\text { Unconditioned } \\
\text { Space: No } \\
\text { system }\end{array}$ \\
\hline 1. & Cooling type & $\begin{array}{l}\text { Direct } \\
\text { Expansion } \\
\text { coil }\end{array}$ & $\begin{array}{l}\text { Direct } \\
\text { Expansion } \\
\text { coil }\end{array}$ & $\begin{array}{l}\text { Water } \\
\text { cooled } \\
\text { screw } \\
\text { chiller }\end{array}$ & $\begin{array}{l}\text { Air cooled } \\
\text { chiller }\end{array}$ & None \\
\hline 2. & Heating type & $\begin{array}{l}\text { Electric } \\
\text { Heat } \\
\text { Pumps }\end{array}$ & $\begin{array}{l}\text { Electric } \\
\text { Heat } \\
\text { Pumps }\end{array}$ & $\begin{array}{l}\text { Electric } \\
\text { Resistance }\end{array}$ & $\begin{array}{l}\text { Electric } \\
\text { Resistance }\end{array}$ & None \\
\hline 3. & Fan control & $\begin{array}{l}\text { Constant } \\
\text { Volume }\end{array}$ & $\begin{array}{l}\text { Constant } \\
\text { Volume }\end{array}$ & $\begin{array}{l}\text { Variable } \\
\text { Air Volume }\end{array}$ & $\begin{array}{l}\text { Variable Air } \\
\text { Volume }\end{array}$ & None \\
\hline 4. & $\begin{array}{l}\text { Coefficient of } \\
\text { performance }\end{array}$ & 2.8 & 3.0 & 5.5 & 3.1 & Not Applicable \\
\hline 5. & HSPF & 1.91 & 1.91 & $\begin{array}{l}\text { Not } \\
\text { Applicable }\end{array}$ & $\begin{array}{l}\text { Not } \\
\text { Applicable }\end{array}$ & Not Applicable \\
\hline 6. & $\begin{array}{l}\text { Air-side } \\
\text { economiser }\end{array}$ & None & None & None & None & None \\
\hline 7. & Heat recovery & None & None & None & None & None \\
\hline 8. & $\begin{array}{l}\text { Zone air set } \\
\text { point }\end{array}$ & $\begin{array}{l}\text { Cooling: } \\
24^{\circ} \mathrm{C} \text { and } \\
\text { Heating } \\
20^{\circ} \mathrm{C}\end{array}$ & $\begin{array}{l}\text { Cooling }: \\
24^{\circ} \mathrm{C} \text { and } \\
\text { Heating } \\
20^{\circ} \mathrm{C}\end{array}$ & $\begin{array}{l}\text { Cooling : } \\
24^{\circ} \mathrm{C} \text { and } \\
\text { Heating } \\
20^{\circ} \mathrm{C}\end{array}$ & $\begin{array}{l}\text { Cooling : } \\
24^{\circ} \mathrm{C} \text { and } \\
\text { Heating } \\
20^{\circ} \mathrm{C}\end{array}$ & Not Applicable \\
\hline
\end{tabular}

\section{Simulation Results}

This calculator can model several combinations of the building type, location, material type, HVAC type and so on leading to millions of combinations. One simple model is simulated as an example case with all HVAC system types and weather data is selected for the New Delhi climate. Area of the model is considered 1600 square meter. Roof reflectivity for white roof is considered 0.8 (initial) and 0.45 (aged) and Grey roof was considered as 0.3 respectively. In all cases, across building types and HVAC system types, the simulations indicate that a cool roof saves energy.

\subsection{Educational Institute Type}

A preliminary analysis has been done for an educational institute type building simulated with all HVAC system types. Input parameters are as per simple model only. Results for the simulation have been presented in Figure 8, and shows annual energy consumption for all end uses. Grey represents a roof with reflectivity SR-0.30, CR (A) is cool roof aged with a reflectivity of 0.45 and CR (I) is cool roof with an initial 
reflectivity of 0.8 . By application of cool roof with surface reflectivity of 0.8 , there is reduction in energy consumption that varies somewhere between 11 to 21 $\mathrm{kWh} / \mathrm{sqm} /$ year. An experimental and calibrated simulation done by A. Bhatia et al. (2011) [15] reports the savings from cool roof over grey roof as $14 \mathrm{kWh} / \mathrm{sqm} / \mathrm{year}$, which falls in this range.

With ageing reflectivity of roof, savings decreases to 3 to $6 \mathrm{kWh} / \mathrm{sqm} /$ year. Among all four HVAC systems, savings decreases with system efficiency increase as shown in Table 3.

Table 3 Annual energy savings for educational institute

\begin{tabular}{|c|c|c|}
\hline System Type & $\begin{array}{l}\text { Annual energy savings } \\
\text { with Cool roof } \\
(\mathrm{SR}=0.45) \text { as compared } \\
\text { to dark roof } \\
(\mathrm{kWh} / \mathrm{sqm})\end{array}$ & 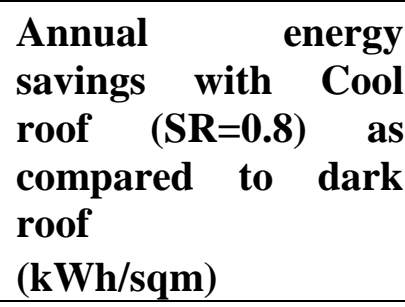 \\
\hline PTHP & 5 & 17 \\
\hline PSZ-HP & 6 & 21 \\
\hline $\begin{array}{l}\text { Central with Air cool } \\
\text { chiller }\end{array}$ & 4 & 15 \\
\hline $\begin{array}{l}\text { Central with Water } \\
\text { cooled Chiller }\end{array}$ & 3 & 11 \\
\hline
\end{tabular}

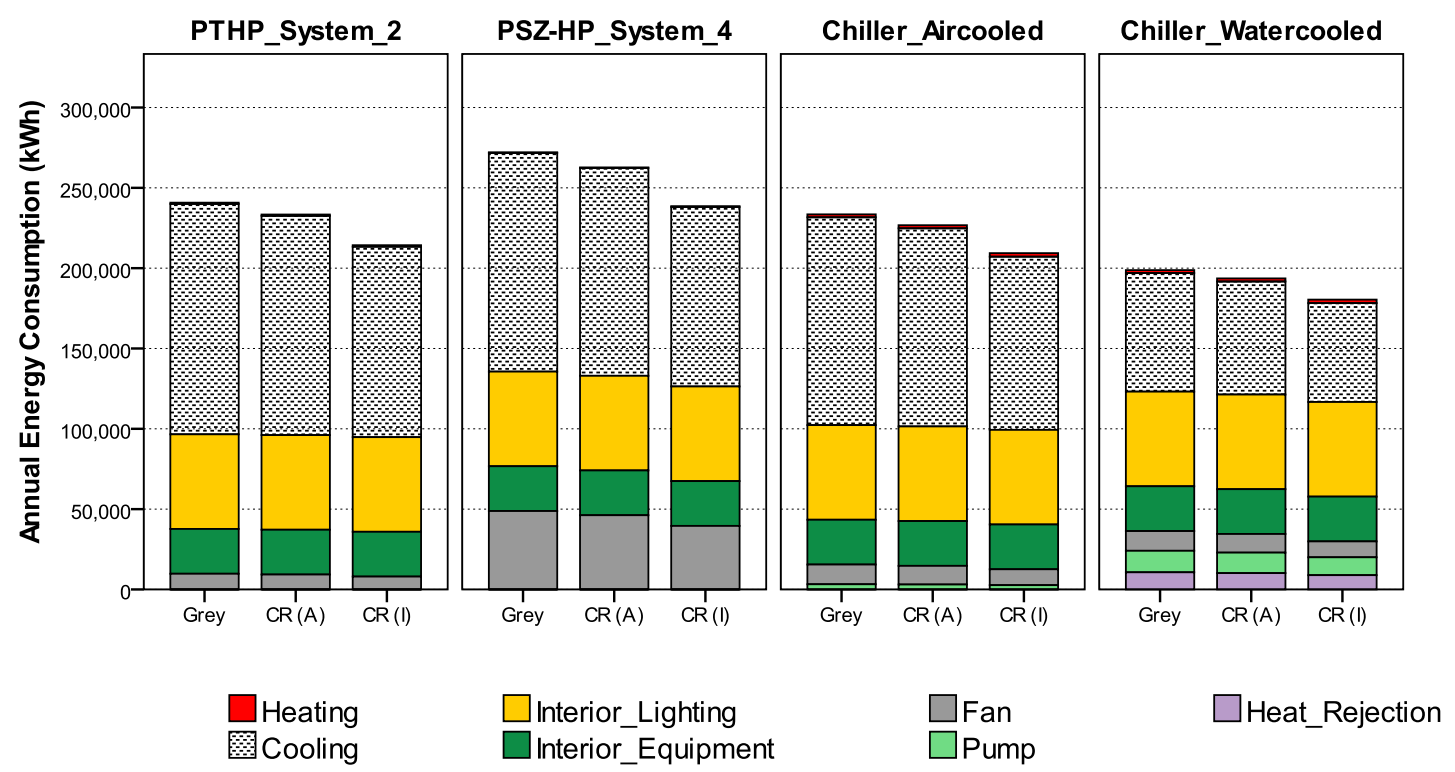

Figure 8 Simulation result for simple institute model 


\subsection{Office Type}

A preliminary analysis has been done for the office type building simulated with all HVAC system types. Figure 9 shows annual energy consumption for all end uses. Grey bar represents a roof with reflectivity SR-0.30, CR (A) is cool roof aged with a reflectivity of 0.45 and $\mathrm{CR}$ (I) is cool roof with an initial reflectivity of 0.8 . By application of cool roof, there is reduction in energy consumption varies between 7 to $16 \mathrm{kWh} / \mathrm{sqm} / \mathrm{year}$. Among all four HVAC systems, savings decreases with system efficiency increase as shown in Table 4.

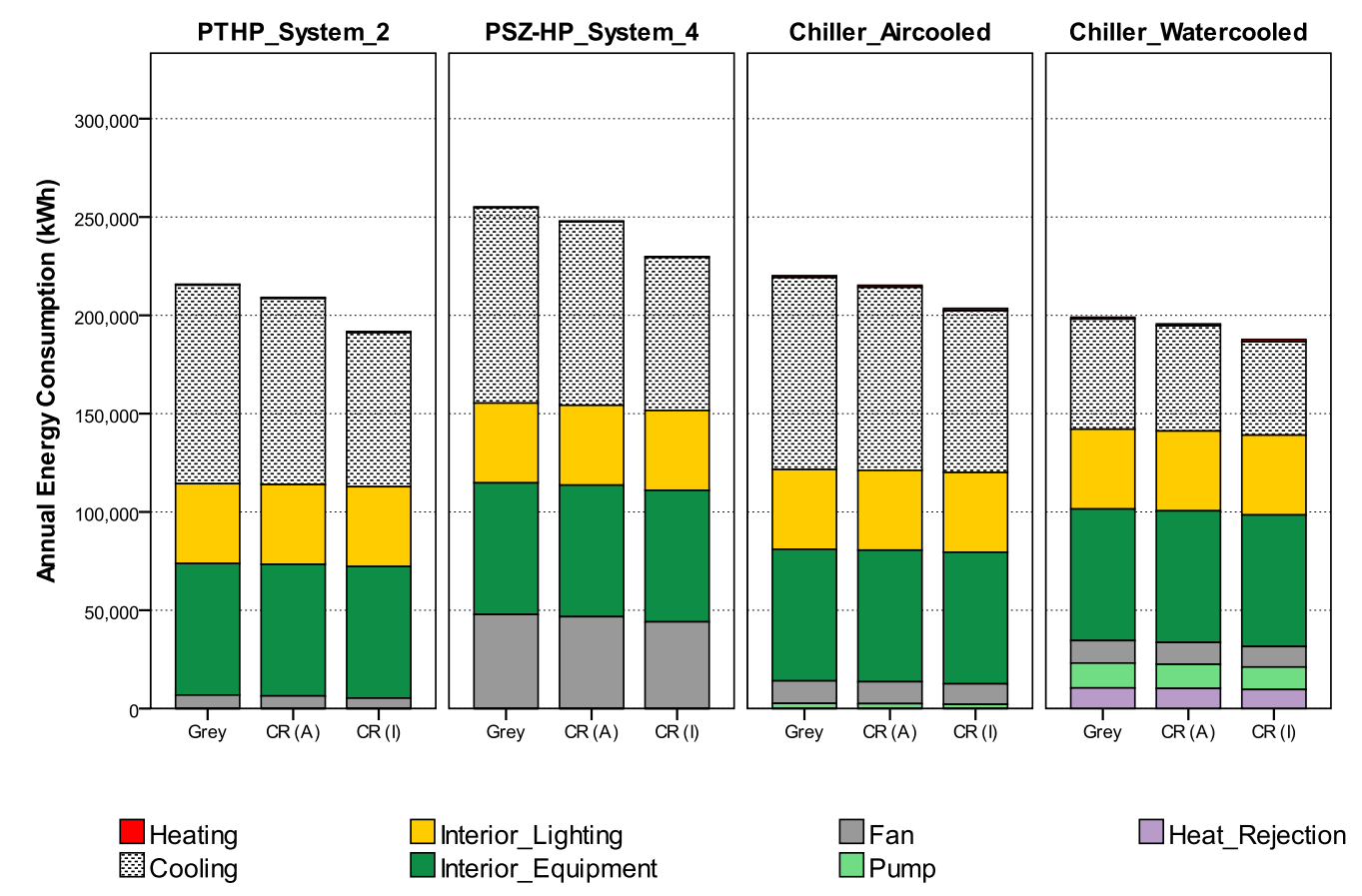

Figure 9 Simulation result for simple office model

Table 4 Annual energy savings for office model

\begin{tabular}{|l|c|c|}
\hline System Type & $\begin{array}{l}\text { Annual energy savings } \\
\text { with Cool roof (SR=0.45) } \\
\text { as compared to dark roof } \\
\text { (kWh/sqm) }\end{array}$ & $\begin{array}{l}\text { Annual energy savings } \\
\text { with Cool roof (SR=0.8) } \\
\text { as compared to dark roof } \\
\text { (kWh/sqm) }\end{array}$ \\
\hline PTHP & 4 & 15 \\
\hline PSZ-HP & 4 & 16 \\
\hline $\begin{array}{l}\text { Central with Air cool } \\
\text { chiller }\end{array}$ & 3 & 10 \\
\hline $\begin{array}{l}\text { Central with Water } \\
\text { cooled Chiller }\end{array}$ & 2 & 7 \\
\hline
\end{tabular}

\subsection{Retail Type}

A preliminary analysis has been done for a retail type building simulated with all HVAC system types. Input parameters are as per simple model only. Results for the 
simulation have been presented in Figure 10 and shows annual energy consumption for all end uses. Grey bar represents a roof with reflectivity SR-0.30, CR (A) is cool roof aged with a reflectivity of 0.45 and CR (I) is cool roof with an initial reflectivity of 0.8 . By application of cool roof there is reduction in energy consumption that varies somewhere between 10 to $23 \mathrm{kWh} / \mathrm{sqm} /$ year. Among all four HVAC systems, savings decreases with system efficiency increase as shown in Table 5.

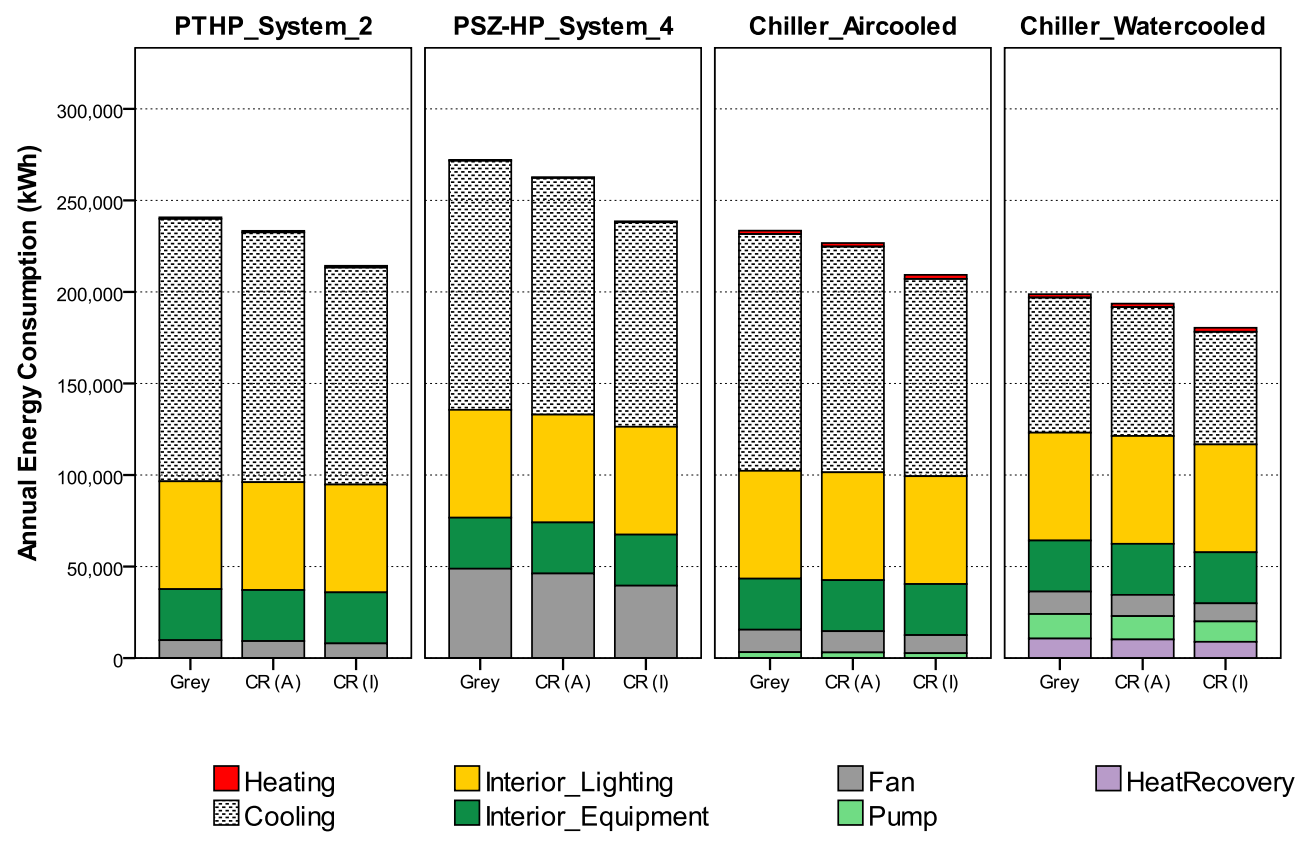

Figure 10 Simulation result for simple retail model

Table 5 Annual energy savings for retail model

\begin{tabular}{|l|c|c|}
\hline System Type & $\begin{array}{l}\text { Annual energy savings with } \\
\text { Cool roof } \begin{array}{c}\text { (SR=0.45) } \\
\text { as } \\
\text { ampared to dark roof } \\
\text { kWh/sqm }\end{array}\end{array}$ & $\begin{array}{l}\text { Annual energy savings with } \\
\text { Cool roof } \\
\text { compared to dark roof } \\
\text { kWh/sqm }\end{array}$ \\
\hline PTHP & 6 & 20 \\
\hline PSZ-HP & 8 & 23 \\
\hline $\begin{array}{l}\text { Central with } \\
\text { Air cool } \\
\text { chiller }\end{array}$ & 5 & 15 \\
\hline $\begin{array}{l}\text { Central with } \\
\text { Water cooled } \\
\text { Chiller }\end{array}$ & 3 & 10 \\
\hline
\end{tabular}

\subsection{Unconditioned Residential Type}

A simulation has been done for an unconditioned residential building. Results of the simulation have been presented in Figure 11 and Figure 12. There is no apparent effect on energy savings by cool roof for unconditioned buildings but a cool roof is capable of increasing the comfort condition inside buildings. To demonstrate the effect, the monthly Mean air temperature for cool roof and Grey roof is shown for all 
months.

Figure 11 shows the change in mean air temperature of the zone with a cool roof. Maximum reduction in temperature observed is $3.9^{\circ} \mathrm{C}$ in month of May. Figure 12 shows change in Fanger's Predicted Mean Vote (PMV) [16] with application of cool roof. Reduction in Fanger PMV in the range of 0.6 to 1.6 has been observed.

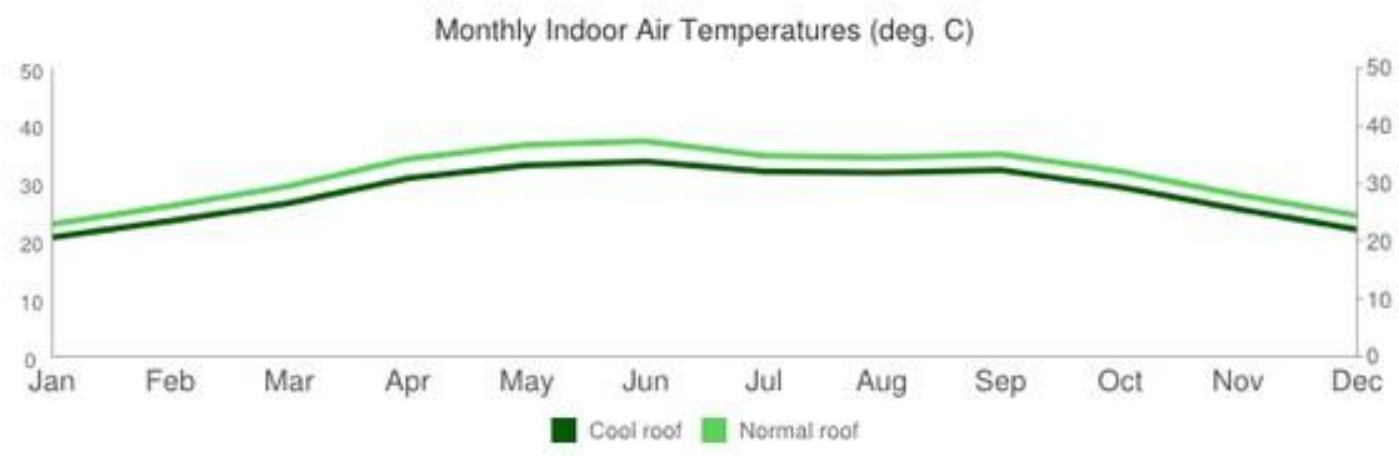

Figure 11 Mean air temperature for unconditioned space

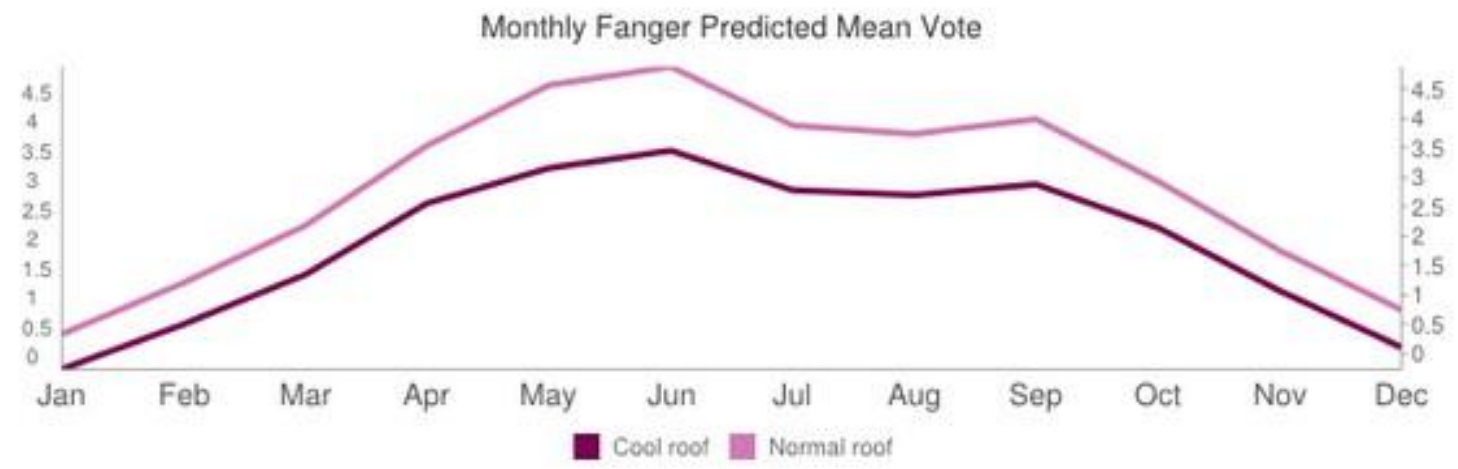

Figure 12 Fanger PMV for an unconditioned space

\section{Parametric Simulation}

The calculator provides parametric simulation results for different insulation thickness with and without a cool roof. Users can select insulation thickness from the curve. The calculator also provides a graph between roof insulation and energy savings from cool roof over a normal roof as shown in Figure 13. 


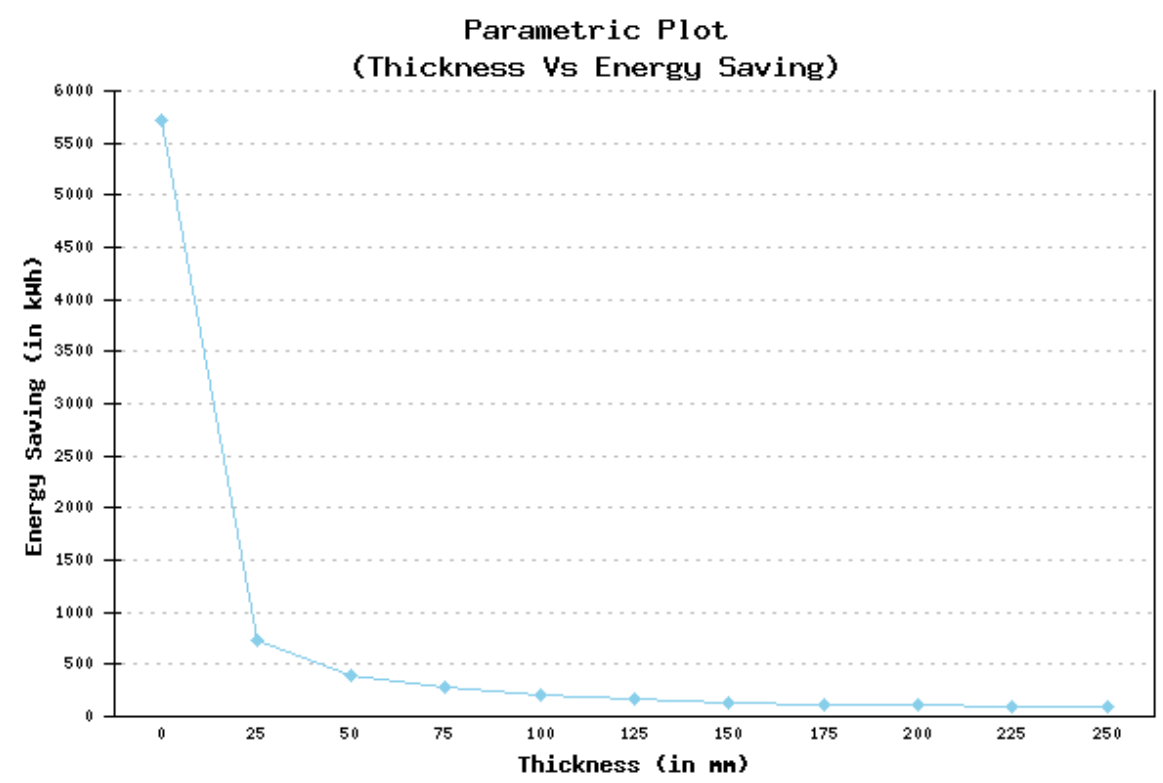

Figure 13 Results from parametric simulation

\section{Stability and Compatibility}

The current version of the calculator has been tested for stability and compatibility. The cool roof calculator is able to handle the computational load and no crash has been observed. The system has a feature to report any network or server failure through email to administrator. It has been tested on the most popular browsers including Mozilla Firefox, Internet Explorer, Google Chrome and Opera.

\section{Caching of Results}

Simulations performed by the EnergyPlus take several minutes to provide output, and hours in case of parametric simulation. It does not make sense to perform simulations which have already been calculated previously. For this, caching is implemented in the calculator. The results given by the simulations are stored in a folder. This folder has a particular ID which is used to refer to the particular simulation. When the simulation is initiated, the inputs received from the POST data of the form are saved into the database along with the ID of the output folder, which is computed at the start of the simulation. After the simulation is completed, the result files are stored in the output folder which are parsed and displayed on the web page.

\section{Conclusion}

A simple calculator has been developed to help users understand the benefits of high albedo roofs in India. Sample results have been provided for New Delhi climate showing around $23 \mathrm{kWh} / \mathrm{sqm}$-year electricity can be saved with application of high albedo roof with 0.8 solar reflectivity. Also, for unconditioned buildings, maximum reduction in temperature observed is $3.9^{\circ} \mathrm{C}$ in month of May and reduction in Fanger PMV in the range of 0.6 to 1.6 has been observed. 


\section{Acknowledgments}

Part of the research which includes improvement of simulation models and addition of unconditioned building analysis was supported by Climate Works Foundation under contract number IIT-10-249. Part of the research including caching of results, parametric simulations was supported by CBERD project. The U.S. Department of Energy (DOE), and the Department of Science and Technology (DST), Government of India (GOI) provided joint funding for work under the U.S.-India Partnership to Advance Clean Energy Research (PACE-R) program's “U.S.-India Joint Center for Building Energy Research and Development" (CBERD) project. The Assistant Secretary for Energy Efficiency and Renewable Energy, Office of Building Technology, State and Community Programs, of the U.S. DOE under Contract No. DEAC02-05CH11231 supports the U.S. CBERD activity. The DST, GOI, administered by Indo-U.S. Science and Technology Forum, supports the Indian CBERD activity.

\section{References}

[1] Cool Roof Rating Council, (n.d.). http://coolroofs.org/.

[2] S.J. Konopacki, H. Akbari, Measured Energy Savings and Demand Reduction from a Reflective Roof Membrane on a Large Retail Store in Austin, 2001. http://eetd.lbl.gov/sites/all/files/lbnl-47149.pdf.

[3] D.S. Parker, J.R. Sherwin, J.K. Sonne, B. Jr, Demonstration of cooling savings of light colored roof surfacing in Florida commercial buildings: our Savior's School, 1996. http://azcoolroof.com/downloads/Resources/Article Cooling Savings of Light Colored Roof Surfacing.pdf.

[4] D.S. Parker, F. Solar, J.R. Sherwin, Comparative Evaluation of the Impact of Roofing Systems on Residential Cooling Energy Demand in Florida, in: ACEEE Summer Study Energy Effic. Build., 2002: pp. 1.219-1.234.

http://www.eceee.org/library/conference_proceedings/ACEEE_buildings/2002/Panel_1/p 1_18.

[5] H. Akbari, H. Damon Matthews, D. Seto, The long-term effect of increasing the albedo of urban areas, Environ. Res. Lett. 7 (2012) 024004. doi:10.1088/1748-9326/7/2/024004.

[6] A. Bhatia, J. Mathur, V. Garg, H. Akbari, Determination of Energy Saving of Cool Roof on an Office Building in Hyderabad, India Using Calibrated Simulation, Sol. Energy Soc. India. 20 (2010) 30-42.

[7] Oak Ridge National Laboratory, DOE Cool Roof Calculator $\square$ : Estimates Cooling and Heating Savings for Flat Roofs with Non-Black Surfaces, (n.d.). http://web.ornl.gov/sci/roofs+walls/facts/CoolCalcEnergy.htm.

[8] J. New, W.B. Miller, A. Desjarlais, Y.J. Huang, E. Erdem, Development of a Roof Savings Calculator, in: Proc. RCI 26th Int. Conv. Trade Show, Reno, NV, 2011: pp. 120 . 
[9] C. Jones, N. Joshua, J. Sanyal, K.-L. Ma, Visual Analytics for Roof Savings Calculator Ensembles, in: Proceeding 2nd Energy Informatics, Atlanta,GA, 2012: p. 492. http://aisel.aisnet.org/sprouts_all/492.

[10] V. Garg, K. Chandrasen, S. Tetali, J. Mathur, Online energy savings calculator for cool roof, in: Clima 2010 - REHVA World Congr. Antalya, 2010.

[11] Building Technology Program: EnergyPlus Energy Simulation Software, (n.d.). http://apps1.eere.energy.gov/buildings/energyplus/ (accessed August 1, 2012).

[12] EnergyPlus Example File Generator, (n.d.). http://apps1.eere.energy.gov/buildings/energyplus/cfm/inputs/.

[13] Apache HTTP Server Project, (n.d.). http://www.apache.org/ (accessed August 1, 2012).

[14] PHP: Hypertext Prepocessor, (n.d.). http://php.net/ (accessed August 1, 2012).

[15] A. Bhatia, J. Mathur, V. Garg, Calibrated simulation for estimating energy savings by the use of cool roof in five Indian climatic zones, J. Renew. Sustain. Energy. 3 (2011) 023108. doi:10.1063/1.3582768.

[16] Franger P O, Thermal comfort, analysis and applications in environmental engineering, McGraw-Hill, New York., 1972. 